Оксана БУТ

\title{
ДІАЛОГ КЛАСИЧНОГО І МОДЕРНОГО НАПРЯМІВ У ЗВУКОРЕЖИСУРІ (До питання визначення професії)
}

У статті розглянуто проблематику термінологічних визначень та складових професії «звукорежскура», запропоновано точку зору на це питання в минулому і сучасності та на особливості класичного й модерного ї̈ напрямів, навчання фаху. Стаття знайомить із провідними постатями у иій сфері.

Ключові слова: звукорежисура, звукорежсисер, фонофіксаиія, звукове рішення, естетика звуку, засоби виразності.

Статья рассматривает проблематику терминологии и составляющих профессии «звукорежсисура», предлагает взгляд на этот вопрос в прошлом и современном контексте и на особенности классического и модерного её направлений, обучение специальности. Статья знакомит с ведущими специалистами в данной сфере

Ключевые слова: звукорежиссура, звукорежиссёр, фонофиксация, звуковое решение, эстетика звука, средства выразительности.

The article examines the problems of terminology definitions and components of profession «Sound production», look at this question in the past and the present, as the features of classical and modern it directions, teaching professions; introduces the leading figures in the specialty.

Key words: sound production, sound producer, sound recording, sound design, aesthetic of sound, means of expression.

Звукорежисура за визначеннями багатьох дослідників (наприклад, В. Дінова, Ю. Закревського, В. Маньковського, Ю. Козюренко, А. Нісбетта, Л. Трахтенберга, Я. Харона та ін.) розглядає майстерність 3 точки зору створення технічними засобами фіксації та обробки звукової картини, що максимально точно передає задум автора (композитора) і створює художній образ, за впливом на глядача тотожний або адекватний «живому», реальному виконанню. При цьому розвінчується думка звичайних слухачів, що фіксація дійсності - це проста технічна маніпуляція за допомогою якісного мікрофона та пристрою звукозапису, що потребує лише дотримання допустимого рівня та натискання кнопок. Заради справедливості зазначу, що багато процесів особливо на телебаченні в умовах обмеженого часу саме так і відбувається - «технічно грамотно, без браку». У згаданих дослідників, зокрема у В. Дінова [1] бачимо такі важливі для творчого маркера визначення, як градація від «мікрофонного прийому акустичних об’єктів» до «фонографічної стилістики». Сучасні дослідники, як П. Ігнатов, В. Дьяченко (недавній захист дисертаційного дослідження якого і послугував поштовхом для написання статті), звертають увагу на еволюцію засобів художньої виразності та створення фонокомпозиції як художньої інтерпретації об'єктів мистецтва. Питання самої термінології в періодизації становлення професії $є$ зовсім непростим. Наприклад, я б уникала у подальших наукових дослідженнях термінів «традиційна» і «сучасна» без відповідного уточнення. Автори так називали запис, здійснений відповідно одним-двома мікрофонами і аналогічний сприйняттю звуку слухачем з найкращого місця колонної зали - і багатомікрофонний/багатоканальний запис 3 можливістю подальшої корекції та зведення. Але для нас, сучасників і той, і другий метод $є$ традиційною (академічною, класичною) школою звукорежисури - ідеологія фіксації звукової картини, максимально наближеної до природного слухового сприйняття. Тому запропо- 
ную використовувати терміни класичного і модерного напрямів у звукорежисурі, що відповідатиме філософії відповідних мистецьких стилів.

Класична звукорежисура, як уже зазначалося, розглядає майстерність 3 точки зору створення технічними засобами фіксації й обробки звукової картини, максимально близької до реального звучання. Але чи завжди виходить очікуваний результат і фіксація є копією (бажаним наслідуванням) дійсності? Зовсім ні. Під час дії навколишнього середовища виникають складні фізичні та психофізіологічні процеси сприйняття потоку звукової інформації й розпізнавання образів - перетворення почутого в поняття та емоційне відчуття. Наприклад, ми присутні на вечірці, де гучно грає музика, відбуваються цікаві розмови. У реальному житті ми налаштовуємося на наших співрозмовників, їх тембр, читаємо дещо по губах, жестах й інтонації. Якщо ми розмістимо якісний мікрофон i зробимо запис у цьому середовищі - то будемо розчаровані, бо мова виявиться нерозбірливою. Цей простий досвід нам показує, що реальність i фонофіксація не тотожні. Для того щоб зробити запис, адекватний сприйняттю нашого слуху, потрібно взяти особливий мікрофон-гармату гіперкардіоїдної спрямованості, що, як прожектор 3 темряви, вихопить для нас на гучному тлі потрібний голос. Або ми можемо взяти індивідуальний мініатюрний петличний мікрофон i розмістити його максимально близько до джерела звуку. Але в цьому разі отримаємо ненатуральний «близький» план голосу, що не створюватиме відчуття перебування на вечірці, але максимально виділить голос 3 натовпу. Всі ці три випадки цілком вписуються в «технічно грамотну фонофіксацію без браку за допомогою якісного мікрофона та рекордера», але представляють абсолютно різні звукові картини, що інтерпретують дійсність: загальнне тло та атмосфера видовища; вибіркове сприйняття напрямку та вихоплення «події», дійової особи в середовищі видовища; якісне донесення інформативної частини про видовище, де останнє відіграє ілюстративну роль, а не активно впливає на глядача/слухача. Таким чином, як і оператор за допомогою оптики, звукорежисер також має можливість наближати та віддаляти звукову картину 3 відповідною мірою трансформації та спотворення тембру і простору в порівнянні з фізичною реальністю. Тобто так само, як мозок людини створює психофізіологічну реальність звукової картини, так звукорежисер віднаходить подібність саме їй 3 мінімальними спотвореннями та збереженням натуральності співвідношень елементів і тембраль- ної окраски. Часто цей результат досягається не під час звукозапису, а у подальшому зведенні кількох одночасно записаних сигналів із різних мікрофонів в одну фонокомпозицію. Саме в створенні цих вражень від звуку реальності, а не фонофіксації й полягає майстерність звукорежисера, що технічними засобами в межах формату (наприклад, моно/стерео) та обмежень тракту - частотного i динамічного діапазону - створює слуховий образ звукової картини за власним художньо-естетичним смаком.

Але навіть цих засобів виразності для сучасної модерної звукорежисури та створення медіапродукту є недостатньо. У перенасиченні інформацією для привернення уваги слід здійснювати психофізіологічний тиск на глядача. Таким чином саме особливими спотвореннями, незвичними обробками, синтезом звуків, нових для слуху, надкрупними планами, що входять у фізичний простір слухача, монтажним та динамічним насиченням, загальною гучністю чи різкістю звучання тощо досягається силуване враження слухача звуком. При цьому такий ефект має найбільшу концентрацію у творах малої форми - трейлерах до фільмів, рекламі, поп-музиці тощо та існує окремо як атракціон у фільмах 4-12D. У трейлерах фільмів це зазвичай різкі динамічні ефекти, швидкий монтаж, пришвидшення музичного темпу та ритму (спільно зі зменшенням тривалості та наповненням рухом кадрів) або насичення певним кольором та атмосферною стилістикою, національним чи фантастично-казковим колоритом 3 використанням класичного саундтреку (яскрава мелодія у виконанні оркестру, особливо магнетичні тембри голосів, буяння незвичних звуків), що цілком відповідає метричному, ритмічному та тональному монтажу за С. Ейзенштейном. Специфіка трейлера полягає також у тому, щоб звучати вражаюче і в просторових системах, і в звичайному стерео. Тому часом трейлери створюють різні: для 3D кіно і звичайної дистрибуції. Перші насичують візуальними і звуковими ефектами, другі драматургічними засобами виразності. I це різні речі. Як кажуть, вухо слухає, а чує мозок. Сучасний кінотеатр здатний змусити вібрувати все тіло людини на фізіологічному рівні. За таким мобілізаційним імпульсом навіть проста, але професійно вибудувана частина історії вражатиме глядача. Ми сьогодні знаємо цілу низку таких фільмів, як, скажімо, «Гравітація» А. Куарона, де весь твір «складений» із сцен-атракціонів ефектів і розкриває всю потужність нової технології або системи (у цьому разі - Dolby Atmos). Деякі студії наперед 
визначають, які сцени будуть задіяні в трейлері та звертають увагу на візуальні та звукові ефекти в них. Загалом для світового кінематографа стало нормою замовляти студіям, що спеціалізуються на цьому, візуальні і звукові ефекти, а кіноакадемія має окрему премію «Оскар» для оцінки цієї роботи. Український кінематограф поки що переважно наслідує традиційні технології виробництва та продюсування, i, відповідно, глядачі часто плутають свої оцінки: «недостатньо видовищний», «зроблений з економним бюджетом» та «нецікавий», «поганий» фільм. Саме вміння не лише створювати ефекти, що впливатимуть на глядача, а й майстерно вплітати їх у канву фільму ще на етапі сценарної роботи та оцінювати їх вартість при можливостях кошторису фільму є надзвичайно важливим набутком. Тому часто саме українські фільми у кооперації або здійснені режисером не українцем, як колись «Тіні забутих предків» так і тепер набувають дбайливого ставлення та міру заглиблення між національним і кінематографічним. Також впливають наші традиційні процеси на час виробництва фільму. Через те, що в Україні ефекти та й взагалі відповідальність за ціле все ще покладаються на особистості, а не на командну роботу, через те, що процеси виробництва запускаються послідовно, а не паралельно (i часто 3 перервами через вичерпаність фінансування) і тим більше не зосереджені на роботі концерну (співдружність профільних студій, що одночасно працюють над різними гранями фільму), - виробництво, а потім дистрибуція розтягується на роки, а не місяці, як це практикується на заході, й ці самі знахідки та технічне втілення ефектів перестають бути вражаючими для глядача. Таким чином, через активну зміну, модифікації, розвиток та вдосконалення технологій і техніки видовищна та звукова частина втрачають свою актуальність при надто тривалому виробництві. Також у роботі концерну практично виключається людський фактор помилки - бо різні служби студій постійно перевіряють одна одну і корегують. Ще Зофья Лісса помітила таку тенденцію: певний сегмент глядачів стверджуватиме, що ефекти, просторовість картинки і звуку тощо - речі напливові, та головне, щоб фільм був хорошим. На жаль, більшість творців українських фільмів займають позицію втілення власних творчих амбіцій та одноосібного керування, ігнорування порад і пропозицій. Тим часом глядачі звикають до максимальних вражень від перегляду і відвідують у кінотеатрі «видовищні» стрічки, решту відклавши для домашнього перегляду. Також рада 3 нагляду кіновиробництва складається переважно 3 режисерів та кінокритиків, а не продюсерів та дистриб'юторів кіно. Тому, можливо, навіть при персональній відповідальності за фільм режисера (у західній практиці це продюсер, що може в процесі замінити і режисера, i будь-яких інших виконавців) ми сьогодні маємо кіноринок із значними перекосами - хороші, потрібні фільми, котрі кладуться на полиці після прем'єри і не мають навіть у намірах дистрибуції, i, навпаки, фільми 3 шаленою рекламою і трейлером, в який вкладено пів-бюджету фільму. Але після прем'єри спрацьовує «сарафанне радіо» реакції глядачів на цілісну картину i, відповідно, відбувається різке падіння/ зростання відвідуваності.

Корінь питання ми бачимо навіть у термінологічних визначеннях процесу. У радянській системі синхронні/не синхронні шуми - у світовій практиці звукові ефекти/атмосфера. Психологічно ставлення до шуму як чогось, що заважає, є мало важливим або просто фізіологічно супроводжує дію, та звукового ефекту, атмосфери як вражаючого елементу, котрий занурює в простір дії. Класична звукорежисура, наприклад, у працях В. Дінова, Д. Гібсона оперує поняттям фонографічної композиції в паралелі з фотографічною композицією. Тобто звучання у просторі розглядаються як сталі елементи, які потрібно розташувати у рамках звукового поля (кадру). За всієї поваги до авторів, сучасне кіно має дуже посутню динаміку в порівнянні 3 минулим часом. Наприклад, багато років поспіль точилася дискусія про переваги цифрового та аналогового звукозапису. Сьогодні вже остаточно можна сказати, що мають рацію... обидві сторони. Просто прихильники аналогового звукозапису подібні до меломанів, які слухають платівки і навіть патефон. Цифровий звук не є гіршим. Він цілком інший: має чітку деталізацію, насичений високими частотами, практично не обмежений за циклами перезапису, кількістю обробок тощо. Навіть штучна механістичність голосу-робота в системах GPS навігації сприймається водіями як привабливість. Тобто переважно негативна оцінка спотвореного голосу в минулому - у сьогоденні позитивна, як «помічника». Реалістичний якісний тембр голосу, який передає практично будь-яка цифрова сучасна техніка, став нормою життя людини. Тому в професійному звукозаписові вже не прийнято приділяти надмірну увагу якості запису, яка апріорі має бути - а більше самому звучанню: натуральності, прозорості, насиченості, деталізації або, навпаки, наслідування аналогової м'якості й теплоти. 
Естетика модерного звуку сформувалася в середовищі електронної музики. У 1980-х британська група Art of noise створила «мистецтво шуму». До творчого осередку, крім музичного продюсера і власне композитора й сесійних музикантів, були залучені інженер, програміст для роботи 3 на той час не дуже типовим і поширеним семплюванням звуків. Тобто метою цієї та подібних груп авангарду електроніки став пошук незвичних звучань та комбінування їх між собою. Більш глобальний розвиток цього явища ми бачимо на прикладі діяльності Р. Майлса та особливо - Пітера Габріела. Продюсерський концерн П. Габріела є флагманом сучасного «саунду», на який орієнтується решта світу. Таким чином маємо ще один термін «word music» - мікшування національних, стильових, жанрових та індивідуальних досягнень сучасної світової культури. До того ж, «авторитети» не варто наслідувати: особливе звучання, що зробило надпопулярним платиновий сингл «Belive» британської співачки Шер - майже моментально стало «штампом» $\mathrm{i}$ «несмаком» у інших спробах повторити цей успіх.

Тлумачення звукорежисури як професії та сфери діяльності (звукооператор, тонмейстер, нім. Tonmeister, франц. - Tonregisseur, англ. - Sound producer) - одне 3 провідних учасників творчого процесу, пов'язаного з акустично-електронними перетвореннями та архівацією звуку у відповідних видах i жанрах музичного та видовищних мистецтв. Як керівник цього процесу, звукорежисер визначає умови створення й бачення звукового образу, зафіксованого на тому чи іншому звуконосієві, що передається в ефір чи відтворюється у просторі через електронно-акустичні пристрої. Витоки професії з часу винайдення механічного (1877), оптичного (1889), магнітного (1898) звукозапису проглядаються у діяльності «керівників запису», «помічників механіка», «техніків» доби фонографа, котрі, для запобігання деформації звуку, розташовували виконавців особливим чином перед апаратом, а під час виконання стежили, щоб при високих і голосних звуках вони віддалялися від рупора, а під час слабких - наближалися до нього тощо. Сама професія звукооператора виникла наприкінці 1920-х - поч. 1930-х, з утвердженням поряд механічного, оптичного та магнітного звукозапису, а на їх основі виникли та стали бурхливо розвиватися радіомовлення, грамзапис i звукове кіно. У 1931 році в Ленінграді відбулася I Всесоюзна акустична конференція. У ній брали участь Центральна лабораторія дротового зв'язку (керівник О. Шорін), лабораторія «Межрабпом- фильма» (керівник П. Тагер), лабораторія тонсектору Київської кінофабрики (керівник І. Нікітін). На цей час в Україні було зроблено два тонфільми: «Симфонія Донбасу» та «Фронт». І. Нікітін та Л. Розенберг мали вже певні досягнення в розробках систем запису звуку на плівку у звуковій лабораторії при тонсекторі (у жовтні 1930) і виступили з чотирма доповідями. У 1932 році Київська кіностудія випустила вже 7 звукових кінокартин, серед яких «Іван» О. Довженка [2, 46-47]. Спершу функції звукорежисера (або тонмейстера майстра звуку) полягали у технічно бездоганній фіксації чи трансляції звукового образу, створеного виконавцями. Основна увага приділялася зниженню рівня сторонніх шумів і становленню загального звукового балансу для забезпечення розбірливості тексту, чіткому прослуховуванню окремих голосів та інструментів при загальному бездоганному ансамблеві. 3 удосконаленням техніки, зокрема появою багатоканальної апаратури, розширенням іiі можливостей починається усвідомлення творчої ролі звукорежисера: він перетворюється на повноправного учасника творчого процесу з розв'язанням не лише суто технічних, а й художніх завдань. Визначаються жанрові особливості звукового рішення в усіх видах мистецтва.

Таким чином, професія стає профільною в таких сферах діяльності, як кінематограф, радіо, телебачення, студії звукозапису, театр та концертні майданчики. Так, студійний запис вимагає створення еталонного звукового образу, з одного боку, i експериментального нового внаслідок пошуків та застосування електроніки - 3 іншого. Навіть у минулому столітті ця тенденція мала місце та простежується від застосування мікрофонного звучання тихих інструментів в оркестрових партитурах С. Прокоф'єва, знахідки обробки голосу та гітари групи Бітлз та інших у естрадній музиці тощо. Натомість пряма трансляція цінується своєю неповторністю, унікальністю, одномоментністю співпереживання події за участю слухачів. Тут важливою $є$ передача індивідуальної звукової атмосфери з притаманними їй сторонніми шумами й виконавськими випадковостями.

Розквіт професії в сфері кінематографа припадає на післявоєнні десятиліття - запровадження й удосконалення технології магнітного звукозапису-відтворення. На кіностудії впроваджено техніку дублювання та випуск національних варіантів фільмів. У 1930 році у Києві був заснований Київський кіноінститут. 3 консерваторії в кіновиробництво прийшли працювати А. Демиденко, Г. Са- 
лов. Після реорганізації кіноінститут перетворився на інститут кіноінженерів, перший випуск яких відбувся в 1947 році. Таким чином на кіностудію прийшли працювати І. Ілюшек, Н. Трахтенберг, А. Грузов, Н. Росохата, О. Матісон. На початку 50-х інститут закінчують С. Остахнович, Б. Остахнович， М. Козін，В. Швачко, В. Ігнатовський, Г. Коломійченко, Г. Матус, О. Тисенко, А. Чернооченко, Л. Вачі, Ю. Риков та ін. Останній випуск цього інституту відбувся у 1955 році [2, 78]. Технічний прогрес 1960-х пов'язаний 3 двоканальною стереофонією і новим поглядом на звучання (новою художньою якістю звучання). 3 монофонічного запису, що обумовлював діалог із глядачем, звук перетворюється на віртуальне середовище, атмосферу події, а глядач - безпосереднього учасника цієї події. У 1957 р. А. Карді винайшов стереофонічний звукозапис на платівку, 1961 рік - святкуємо як День народження стереофонічного мовлення; у 1963 році вийшла перша стереофонічна магнітна компакт-касета. 3 середини 1970-х - поява цифрової техніки звукозапису і відтворення (стандарт CD прийнятий у 1982 році), стереофонії й іiі варіантів (зокрема квадрофонії, Dolby A, Dolby SR), багатоканальних комплексів, що стали сьогодні стандартами (Dolby Digital 5:1) а також SDDS та DTS; різного роду процесорів обробки звуку - акустичні фільтри, ревербератори, компресори тощо; приладів для синтезування (створення) нових звуків, семплерів - та об'єднання всього циклу робіт від запису до майстерингу на програмно-апаратному комп'ютерному комплексі - відкривають безмежні можливості маніпуляції зі звуком у кіно. Розвиток телебачення, студій звукозапису, тотальна радіофікація та звукопідсилення концертних майданчиків i стрімка «електронізація» музичних інструментів суттєво розширюють сфери діяльності музичної звукорежисури, роблять цю професію масовою й ведуть до подальшої іiі диференціації, як, скажімо, звукорежисура конкретного музичного, зокрема естрадного колективу. Так, суто технічне обслуговування надскладної апаратури переходить до звукоінженерів, звукотехніків, монтажників. У наш час звукорежисер стає основним інтерпретатором і реалізатором ідеї автора й виконавців у створенні звукового образу, а в естрадній та електронній музиці - подекуди й безпосереднім співавтором. Згадаймо, принаймні, так званого «п'ятого» з Бітлз - Б. Епстайна та першого звукорежисера групи - Дж. Мартіна. У свою чергу деякі функції звукорежисури переходять до виконавців, які самостійно використовують на сцені прийоми «мікро- фонного» співу, можливості деформації звуку, що iii надають сучасні електронні музичні інструменти, зокрема електрогітари та синтезатори, а також передбачають для виконавців і композитори, які працюють у сфері комп'ютерної музики.

3 розвитком комп'ютерної техніки сучасна якість звукозапису та обробки стала доступною не лише вузькому колу спеціалістів галузі індустрії, а й широкому загалу шанувальників. Це дало поштовх до обладнання «домашніх» та «персональних» студій-лабораторій, вільного розміщення продуктів творчості в Інтернеті, бурхливого розвитку жанру електронної музики тощо.

Професія звукорежисера вимагає не лише грунтовних технічних знань, вільного володіння спеціальними навичками, а й музичної освіти, глибокого розуміння суті творчого процесу. Тож правомірним стало навчання цій спеціальності у вищих навчальних закладах України. У 1991 році на базі кафедри телережисури факультету кіно і телебачення КІТМ ім. І. К. Карпенка-Карого (зараз КНУТКТ) В. Лукаш провів перший набір за спеціальністю «звукорежисер». 3 того часу звукорежисерів навчають у КНУТКТ ім. І. К. Карпенка-Карого, КНУКІМ, ДАКККІМ, КВМУ ім. Р. М. Глієра, інститутах перепідготовки та підвищення кваліфікації кадрів. Також звукоінженерів готують на факультеті електроніки та радіотехніки НТУ (КПІ). Останнім часом навчальні заклади та автори навчальної літератури (А. Севашко, Б. Меерзон та ін.) повсюдно застосовують термін «звукорежисер» як всеосяжний для всіх напрямів діяльності. Енциклопедичне визначення суті та призначення звукорежисури як професії узагальнює всі попередні назви як більш ранні та історичні. Водночас терміни «тонмейстер», «музичний продюсер», «звукооператор» та «звукорежисер» дуже відрізняються за суттю. На конференціях, присвячених навчальному процесові, зазначається, що розглянута вище специфіка роботи, зокрема в таких сферах, як радіо, театр, музична звукорежисура, розглядається побіжно, а не в обсязі потреб цих напрямів (Третя міжнародна науково-практична конференція «Режисура екранних мистецтв: актуальні питання професії, методологія навчання», КНУТКТ, 2021.02.2018). Цьому питанню також присвячена стаття М. Ужинського «До визначення сутності професії звукорежисера в сучасному мистецтві». Але дослідник пропонує, як і інші автори, навчати спеціаліста широкого профілю, що на обраній ділянці роботи у виробництві опанує специфіку окремої галузі. Частково у межах місячних курсів 
підвищення кваліфікації та семінарів такі завдання почав виконувати Укртелерадіопресінститут, зокрема в сфері радіо, бо саме специфічних знань i не вистачає для поштовху і розвитку окремої ланки виробництва. Тут маємо і законодавчу колізію - у переліку спеціальностей немає профільного різноманіття, пов'язаного, зокрема, з музичною звукорежисурою. Тонмейстер (Tonmeister) майстер звуку, що створює гучність, тембр і просторові характеристики звукового образу в художньому та технічному аспектах, відповідно, користуючись такими параметрами, як: прозоpicmь - чіткість звучання, гарне прослуховування всіх звукових ліній партитури, розбірливість; просторовість - звукова перспектива (природна чи штучна), просторове враження (акустичний баланс), відповідність акустичного середовища жанру і типу музичного твору (недостатня, оптимальна або завищена), також відповідність історичній традиції виконання, скажімо, творів Моцарта в невеликих салонах, домах знатних осіб, а творів Ліста та Рахманінова - у великих концертних залах зі значною реверберацією; музичний та ансамблевий баланс; відповідність тембральна та звукового плану - скажімо, на помилково обраному крупному плані скрипка може зазвучати як альт, а голос оперного співака «здушеним» $\mathrm{i}$ різким; відповідність технічним та художнім вимогам запису певного призначення (динамічний та частотний діапазони, моносумісність або просторові ефекти, частотні, фазові та амплітудні спотворення, акустичні перешкоди і випадкові шуми) і якість регулювання параметрами (непомітність); загальна художня оцінка - цінність, ідея та цілісність сприйняття, відповідність тембру голосу виконавця (фонічне трактування) або провідного інструмента (аранжування чи інструментовка) художньому образу, трактування забарвлення звучання (використання звукових ефектів), трактування виконання твору (інтонаційне, темпове, динамічне, акценти-наголоси, паузи тощо). Музичний продюсер (Sound producer) має на меті формування не окремого музичного твору, а комплексного проекту, де підбираються автори текстів і музики, виконавці та їх «імідж» (сценічний образ) у технічному та художньому втіленні низкою професіоналів певних галузей, вироблення звукового та аудіовізуального продуктів та ін. У західному варіанті співпраці в студії зазвичай на сесію звукозапису збираються виконавці, музичний продюсер та звукоінженер. Таким чином, це музичний працівник, який повністю відповідає (в художньому та фінансовому аспекті) за якість звукового продукту (ідею звукового рішення, майстерність виконання та відповідність твору образу і жанру колективу, технічну якість). Також в Україні практично немає спеціалістів, здатних здійснити майстеринг музичного продукту.

Звукооператор, цей термін, як і багато інших радянських термінів, - синхронні та несинхронні шуми, звукові паузи тощо - має умовний характер на позначення професіонала, який працює зі звуком у кіно. Можливо, на зорі кінематографа в цьому напрямі й працювали «випадкові» люди 3 технічною освітою, які виконували роль операторів звуку - тобто забезпечували якісний запис-перезапис звукової доріжки. Але з часом звукооператори перестали обмежуватися цим винятково технічним завданням. Хоча у західних технологіях виробництва фільму звук створюється колективом вузькогалузевих спеціалістів: редакторів звукових ефектів та текстів (Sound Effects, Dialoque Editor), мікшувальників реплік та звукових ефектів (Foley, Sound Mixer), мікс-режисерів перезапису (Re-Recording Mixers), музичних редакторів (Music Editor), аранжувальників та авторів електронної концепції (Orchestrations and Electronic Score Producer), а також інженерів звуку (sound technician). Певну аналогію творення звукової концепції фільму в західному кіно має звуковий дизайнер (Sound Designer). Хоча його робота найчастіше обмежується ефектними в звуковому плані сценами багатоканальних систем кіно, а не концепцією звукового рішення фільму в цілому. Рядянська технологія майже одноосібної відповідальності за звук у фільмі (іноді окрім запису та зведення музики) підштовхнула звукооператора до творчих експериментів і відповідних вимог до професії: «Він має розбиратися в літературі, розуміти музику, творчий задум режисера, композитора, виконавців, зв'язок між звуковими і зоровими складовими, знати телевізійні та кінематографічні здобутки, а також сучасні тенденції розвитку техніки та мистецтва звукозапису» [3]; те саме в іншому не менш знаному виданні Л. Трахтенберга «Майстерність звукооператора», що бачимо навіть 3 назви книжки. Специфічні особливості практичної роботи профільних спеціалістів у сучасному кіно можемо вивчати переважно за європейським досвідом, зокрема документальними стрічками про створення знакових фільмів та циклами передач телеканалу Дискавері про роботу «концернів мрій».

Посада «Звукорежисер» від початку існувала на телебаченні. Але з огляду на потоковість i 
масовість роботи (великий масив матеріалу для ефірного часу) часу на режисуру звуку зазвичай на телебаченні не вистачає.

Багато в спогадах режисерів, зокрема О. Довженка написано про майстерні та навчання майстерності. Також існує практика опанування цього ремесла не у вузі, а безпосередньо на виробництві. Звукорежисерську, як і операторську майстерність та інші спеціалізації галузі неможливо відділити від виробничої практики, а також переймання досвіду поза навчальним закладом. Тому важливим було б пригадати майстрів звукорежисерської діяльності. Перелік імен звукорежисерів другої половини XX століття наведено наприкінці статті*.

Це далеко не повний перелік фахівців, відзначених в Україні та за іiі межами. Довідкової літератури на кшталт праці О. Литвинової «Музика в кінематографі України. Каталог» не існує. На жаль, як показує досвід, активний діалог між представниками виробництва та навчальними закладами, що випускають спеціалістів для роботи у цих сферах, відбувається переважно в сферах кіно, телебачення та студійної/концертної звукорежисури. Практично немає наукових досліджень, підручників та довідників, періодичних видань професійного спрямування, а публікації в Інтернеті не завжди є достовірними та професіональними. Таким чином виникає колізія, де постаті професіоналів, які зафіксували непересічні виконання творів класики і сучасності, створили цікаві звукові рішення кіно, телефільмів і радіопередач, концептуальне звучання музичних проектів тощо, лишаються невідомими широкому загалу. 3 іншого боку, представники кожної сфери мають власне уявлення про професійні навички, здібності та творчі якості працівника галузі в спеціальності «звукорежисер».

\footnotetext{
Звукорежисери на радіо: багато років справі музичної звукорежисури у Будинку звукозапису Національної радіокомпанії України (РБРЗ з 1956 р.) віддав Л. Бильчинський. У 1994-2004 рр. Л. Бильчинський викладав звукорежисуру в КНУТКТ ім. І. К. Карпенка-Карого. Його учнями себе вважають відомі укр. звукорежисери М. Дідковський, А. Мокрицький, Т. Сотникова, В. Щегольський, Ю. Щелковський, Т. Вінницька. Ініціатором відкриття Української філії Всесоюзної студіï грамзапису фірми «Мелодія» та іiі багаторічним звукорежисером (1968-93) був Ю. Вінник, який на поч. 1960-х здійснив перші в Україні стереофонічні записи. А. Мокрицький, 1962 р.н., за запис музики до ювілейного концерту Н. Матвієнко «Золотий камінь посіємо» (музика Г. Гаврилець, 1997 р.) та камерного хору «Київ» «1000 років української духовної музики» (1996 р.) як один 3 авторів проекту отримав Шевченківські премії. Записи А. Мокрицького «Концерт для скрипки 3 оркестром» Е. Блоха та Б. Ліза у виконанні
}

Е. Олівери у 2009 році були представлені на премію Греммі.

Звукорежисери в кіно. Художніх фільмів: Л. Вачі та С. Вачі, Г. Салов та О. Салов, А. Підлісний та Г. Підлісна, Т. Нілова, Г. Калашникова, В. Сулимов, Г. Чупаков, Р. Крупєніна, Ю. Риков, Ю. Горецький, Є. Пастухов, Т. Чепуренко, Н. Серьга, В. Брюнчугін, Б. Міхневич, Ю. Лавриненко, Ю. Винарський. Л. Цельмер, провідний звукорежисер Національної кіностудії ім. О. Довженка, озвучила кінофільми «Богдан Хмельницький» (2003); також свого часу популярні зимові новорічні казки: «Ніч перед Різдвом» (2002), «Весілля Фігаро» (2003), «Вечори на хуторі біля Диканьки» (2004). Н. Домбругова, заслужений працівник культури України, з 2000 року викладає звукорежисуру у вузах Києва, завідувач кафедри звукорежисури в КНУТКТ, звукооператор фільмів: «Одиниця 3 обманом» (1984), «Версія» (1986), «Чорна яма» (1987), «Балаган» (1990), «Декілька любовних історій» (1994), «Москаль-чарівник» (1995), «Таємний щоденник Симона Петлюри» (2018) та ін. В. Лукаш, заслужений працівник культури України, перший завідувач кафедрою звукорежисури в КНУТКТ, голова Гільдії звукорежисерів НСКУ, звукооператор фільмів «Розпад» (реж. М. Бєліков, «Золотий лев» Венеціанського фестивалю), «Повернення з орбіти» (реж. А. Сурін, Золота медаль Паризького фестивалю). Телефільм «Невідомий, якого знали всі» (Вл. Луговський, 4 серії) вважає своєю найкращою звукорежисерською роботою. Документальних фільмів: О. Рєнков, Г. Стрємовський, І. Барба. Зокрема, Л. Рязанцев - звукорежисер фільмів «Чорнобиль. Хроніка важких тижнів» отримав Державну премію, «Вічний хрест» - приз Міжнародного телефестивалю «Бархатний сезон» (2003), «У неділю рано» - приз «Золотий дракон» Міжнародного кінофестивалю в Кракові (1988), «Суфлер» - диплом Міжнародного кінофестивалю (Лілль, Франція, 1982), «Меланчине весілля» - приз «Срібний голуб» Міжнародного кінофестивалю (Лейпціг, НДР, 1979), «Мужчини і жінки» - гранпрі Міжнародного кінофестивалю (Реймс, Франція, 1973).

Телефільмів: Г. Медведєва, начальник відділу звукорежисерів Національної телекомпанії України. 1980 - 1986 рр.- провідний звукорежисер студії «Укртелефільм» відділу постановчих відеофільмів. Професіональну роботу на телебаченні Й. Тетяни, I. Четверенової також відзначають колеги по цеху. Хронікальних, науково-популярних та анімаційних фільмів: І. Погон, К. Коляда, Л. Роман (понад 200 стрічок). Зокрема Л. Мороз, заслужений працівник культури України, багато років викладав у ДАКККІМ, звукооператор фільмів «Чи думають тварини», «Сім кроків за горизонт», «Вісім тактів забутої музики»; мультфільмів: «Як козаки в футбол грали», «Теплий хліб», «Людина, яка вміла літати», «Кит і Кіт», «Людина і слово».

Звукорежисери театру: О. Лінецький (театр Російської драми), В. Шпаковська (театр маріонеток), В. Кожевников (Вільна сцена), Д. Богомазов (Сузір'я, також працював звукорежисером на концертах С. Ротару), В. Борисов (театр на Подолі та 
ТЮГ), І. Дядько (Театр пластичної драми). О. Курій (театр Драми і комедії на Лівому березі, театру, «Київ Модерн-Балет») - саунд-продюсер кінокомпанії «Fresh Production», багаторазовий лауреат премії «Київська пектораль», саунд-продюсер фестивалю «Золота корона», звукорежисер фестивалю «Сходи до неба», «Таврійські ігри» та незмінний учасник найскладніших електроакустичних проектів у Києві та фестивалю сучасної електронної музики («Час Простір Музика», 2000, «Електроакустика», 2003, 2005, 2007, «ЕМ-візія» 2005, 2007) та ін.

Звукорежисери запису сучасної музики: М. Дідик (студія звукозапису КІМ ім. Р. Глієра), М. Павлов (студія «Мікс»), О. Саранча, Є. Ступка і О. Ступка (студія «Лемма»), В. Григорович (студія «М. Дідковський, І. Прима, А. Сасько», Велика і мала концертна студія Будинку звукозапису НРКУ), І. Завада («VL RECORDS»), К. Костенко, О. Репецький («Комора»), В. Сватенко («Студія ЛЕВА»), А. Віхорєв («Аркадія») та ін.

Звукорежсисери шоу-вистав $і$ концертів: В. Коломієць («Комора»), Ю. Звягінцев (палац «Україна»), В. Лещенко, В. Папченко,В.Колісник, Ю. Лінник (пісенний конкур «Таврійські ігри»), О. Балабан («Нова хвиля») та ін.

\section{Джерела та література}

1. Динов В. Звуковая картина / В. Динов. - СПб. : Геликон Плюс, 2002. -366 с.

2. Фількевич М. Довженківці: сторінки нашої історії ; авт.-упоряд. Галина Фількевич, Георгій Фількевич / М. О. Фількевич. - К. : Стилос, 2006. - 178 c.

3. Маньковский В. Основы звукооператорской работы : Учебное пособие / В. Маньковский. - М. : Искусство, 1984. $-240 \mathrm{c}$

4. Трахтенберг Л. Мастерство звукооператора / Л. Трахтенберг. - М. : Искусство, 1972. -191 с.

\section{References}

1. Dinov, V. (2002). Zvukovaja kartina. - St. Peterburg: Helicon Pliys, 366 [in Russian].

2. Filkevitch, M. (2006). Dovgenkivci: storinky nashoj istorij. Kyiv: Stylos, 178 [in Ukrainian].

3. Mankovskij, V. (1984). Osnovy zvukooperatorskoj raboty. Moscow: Iskusstvo, 240 [in Russian].

4. Trahtenberg, L. (1972). Masterstvo zvukooperatora. Moscow: Iskusstvo, 191 [in Russian]. 